\title{
The Changing Role of the Federal Reserve
}

\author{
Frederick H. Schultz
}

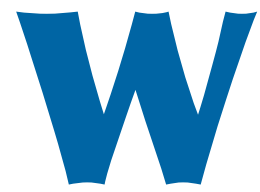

hen I went to Washington in 1979, most people thought the Federal Reserve was either a bonded bourbon or a branch of the National Guard. In those days, stabilization theory, which is an economist's way of saying steady growth, was based on changeable fiscal policy and steady monetary policy. The Fed was a low-profile institution. Milton Friedman was the most visible of the monetarists, and he went so far as to say that we might even be able to do away with the Federal Reserve. He wanted to put monetary policy on autopilot, and he regarded fine-tuning as the worst possible option. Now we have a system in which there is almost universal agreement that we ought to have a budget that is in surplus and a Federal Reserve that should be flexible in monetary policy in order to respond to changes in the economy. To Milton Friedman's consternation, Alan Greenspan is the greatest fine-tuner in history. We have come a full 180 degrees in the past 20 years.

Why did that happen and what kind of an organization is the Federal Reserve? A little history. In 1913 the Federal Reserve was created, primarily to respond to financial panics. In rural areas, the agricultural banks would be fully committed to commodity loans. Sometimes there would be a sharp drop in prices and people would want to take their deposits out of the banks. The banks would call their loans, farmers would fail, there would be a run on the banks, and both farmers and bankers would be bankrupt. The Federal Reserve was created as a lender of last resort so that the banks could borrow from the Fed until prices stabilized. In the urban centers, excessive speculation in financial markets sometimes caused short-term distress. Again, the Federal Reserve could provide the banks with liquidity until prices stabilized. The system worked reasonably well for several years, including 1921, when we had a sharp drop in commodities.

But when the Great Depression hit in 1929, a combination of errors in judgment and structural flaws prevented the Fed from adequately responding. Structural problems were threefold. First, the Treasury Secretary sat on the Federal Reserve Board, so decisions were politicized. Second, the nation was on the gold standard, which required the Federal Reserve to be shrinking the money supply during a time when it should have been increasing it to fight deflation. Third, the Federal Reserve did not have authorization to buy and sell in the open market, a capability used to steady the money supply. I remember that one of the first shocks that I had after getting on the Board was related to open market operations. Every Monday the staff at the New York Fed and the staff in Washington did (and still do) their calculations to come up with an agreement on how much money needed to be injected into or removed from the system. I had been on the job for a week when they made the request to pump $\$ 3$ billion into the market. That was the first $\$ 3$ billion decision I ever had to make.

The National Banking Act of 1935 fixed the structural problems but still required the Federal Reserve to buy any bonds that were issued by the federal government, with the result of monetizing the debt. This inflationary threat was changed by the Treasury Accord of 1951. Since that time, the Fed has had a high degree of independence.

What kind of organization is the Federal Reserve? There are about 25,000 employees.

Frederick H. Schultz was Vice Chairman of the Board of Governors of the Federal Reserve System from 1979 to 1982.

Federal Reserve Bank of St. Louis Review, March/April 2005, 87(2, Part 2), pp. 343-48.

(C) 2005, The Federal Reserve Bank of St. Louis. 
Policymaking is the exclusive domain of the seven members of the Board of Governors in Washington. They are all appointed by the President and confirmed by the Senate. The Chairman and Vice Chairman are confirmed separately, first as Governor and then as Chairman or Vice Chairman. There are about 1,500 employees in Washington. One of my responsibilities was as the administrative governor in charge of the Washington staff.

There are 12 Federal Reserve Banks and more than 40 branches. Most activity at these institutions involves clearing checks and acting as the fiscal agent for the government, primarily selling bonds and accepting various kinds of government deposits. Although the Federal Reserve Banks can request changes in the discount rate, they don't have any policymaking duties other than those delegated to them by the Board of Governors in the area of bank supervision and regulation.

However, they are the eyes and ears of the Fed. There are 300 economists at the Board in Washington and an equal number in the Federal Reserve Banks. The governor of the Bank of England once told me that compared with the Federal Reserve, the Bank of England is a Toonerville Trolley. You may read newspaper reports about the "Beige Book," which is made up of reports from the economic staff of each of the Federal Reserve Banks. It is used as an important source of information in setting monetary policy. When I went to the Board, we were shorthanded and Chairman Paul Volcker asked me to be not only the administrative governor but also chairman of bank activities, which meant that I had oversight for all of the Federal Reserve Banks. This required me to visit each of the Banks on a regular basis to meet with their president and board of directors, which helped me to understand what was happening in each section of the country.

Monetary policy is decided at meetings of the Federal Open Market Committee (FOMC), composed of the seven governors and five of the twelve Federal Reserve Bank presidents, who rotate their service on the FOMC. The FOMC meets about every six weeks. During the time I was there, Volcker and I often had dinner the night before each meeting. As Vice Chairman, I had decided that I would never vote in opposition to Paul on matters of monetary policy, although he and I were on opposite sides in a number of regulatory and supervisory matters. During dinner I would express my views on the economy and monetary policy. We would debate those views, and Paul would outline the direction he wanted to take. The next morning the meeting would begin with staff reports on the domestic economy, the international economy, and various monetary options. Then we would go around the board table and each governor and Federal Reserve Bank president would give his views. We would then have a recess and the president of the Federal Reserve Bank of New York, the staff director for Monetary Policy, and I would join Paul in his office to discuss what we had heard. When we reconvened, Paul would do a masterful job of pulling everything together and proposing a course of action. Debate would ensue and a vote would be taken. If there were not at least ten affirmatives, Paul would propose an alternative. This would continue until there was substantial agreement.

What's it like to be a governor of the Federal Reserve? In my case, I was appointed because no one else wanted the job. For two years I had been on the board of the National Institute of Education. When Congress created the new Department of Education, I was on the list to be considered for secretary. In those days, Charles Kirbo, the senior partner of King and Spalding in Atlanta, was Jimmy Carter's closest advisor. He vetted all the major appointments. We had a meeting, and after about 45 minutes he asked me if I would come to Washington for anything else. When I replied in the negative, he asked about the Federal Reserve, which I found interesting. I found out later that they had been trying to find a banker from the South to put on the Board. They talked to a couple of the CEOs of major banks who turned them down because of the requirement to sell all bank stocks.

My conversation with Kirbo was on a Monday. On Wednesday I got a call from Bill Miller, who was Chairman of the Federal Reserve Board, asking me to come to Washington for lunch on Friday. I flew up and we talked for about two hours. At the end of our discussion, he asked if I would accept 
an appointment if offered. I told him that I could give him an answer on Monday after discussing it with my wife over the weekend. When I called Monday to tell him that I would be willing to accept, he indicated that I needed to be interviewed by the Vice President and the Secretary of the Treasury. He set up an appointment for the next day, and I flew back up for meetings with Vice President Mondale and Secretary Blumenthal. Wednesday morning Chairman Miller called to say that, after their approval, my name had been submitted to the President. At this point I thought the process would slow down, but on Friday I was informed that the President had sent my name to the Senate. On Monday I called a press conference for that afternoon, only to be informed that morning that the President had also decided to nominate me as Vice Chairman. Obviously, I was a little breathless from the speed of events.

When the confirmation process began, I understood that it would take some weeks, so I decided to accelerate my learning curve. When I had been a Kennedy Fellow at Harvard, I had audited a graduate course on macro-economics. I called the professor and asked him if he could put together a group of outstanding economists for a meeting. When I arrived in Cambridge, he had seven economists for lunch. Four of them were Nobel Laureates-Bob Solow, Ken Arrow, Paul Samuelson, and Franco Modigliani. We had lunch and spent the afternoon talking. I was trying to get their advice on what steps we should be taking in handling monetary policy. It was a wonderful afternoon and I learned a lot, but I also heard many comments that on the one hand we should do this and on the other hand we should do that. I remembered that Harry Truman once said, "For God's sake, give me a one-armed economist." After the meeting, Franco said that he would drive me back to the hotel. As we raced down city streets at 70 m.p.h. in his Italian sports car, Franco was gesticulating not just with one hand but with both, so I also learned that afternoon never to ride in a sports car with an Italian economist.

I then decided to try to meet with the major bankers in New York, since the Federal Reserve has regulatory responsibility for bank holding companies. After meeting with Walter Wriston at
CitiCorp and John McGillicuddy at Manufacturers Hanover, I went in to see David Rockefeller at Chase. He came bounding out of his office, grabbed me by the hand, and said, "Governor, it's nice to meet my new boss." When I got to know him better later on, and when I learned more about my new job, I understood he wasn't just blowing smoke.

My confirmation was difficult. Senator William Proxmire, chairman of the Senate banking committee, felt that I was not qualified to be Vice Chairman and preferred that one of the older, more experienced members of the Board be chosen for that office. I met with each member of the Senate banking committee, with the exception of the chairman, who chose not to see me. Several of the Democratic senators were opposed to me because of my business background. The issue remained in doubt until the day of the Committee vote. I finally prevailed 12 to 10, with all Republican senators voting for me. Two and a half years later, when I was planning to leave the Board, Senator Proxmire took the floor of the Senate to comment, "Fred Schultz has done a fine job in a very difficult time."

I was sworn in on a Wednesday. On Friday, Bill Miller called to say that he was resigning as Chairman of the Board to accept the position of Secretary of the Treasury. My reply was "Well, thanks a hell of a lot." Over the weekend the rumor went around that I was to be the next Fed Chairman. Monday morning was the most humbling experience of my life. The currency markets opened in Europe and the dollar dropped like a rock. That afternoon the President announced that Paul Volcker was going to be the next Chairman, and the dollar shot right back up again.

During this time, the economy was really beginning to deteriorate. The summer of 1979 was certainly the most difficult economic crisis this country has experienced since the Great Depression. There was a growing flight from the dollar. Everybody was getting out of intangibles and into tangibles. They were selling stocks and buying real estate or gold or jewels or stamps or anything to protect them against inflation. One of the members of the Board was a great international economist named Henry Wallich. He had been a young boy in Germany in 1923. He used to tell a story that 
he would go down to the community swimming pool where the nominal charge for an eight-yearold boy was 5 billion marks. He had to get a large basket and fill it with currency in order to go swimming. In those days people in Germany were paid twice a day. They were paid at noon and took their check and spent it immediately because between noon and the time they got paid again at 5:00 the value of the currency would have already dropped dramatically. Wallich used to say that he never, never thought these things could occur in the United States. But in the summer of 1979, he used only one never.

Chairman Volcker recognized that he needed to do something dramatic, so he proposed that we adopt a strict monetary rule based on movements of the money supply. We understood that interest rates would have to go up very sharply, but none of us believed that they would go as high as they did. We rather thought that 15 percent would do the job, but the prime actually went as high as 20.5 percent. It was a very difficult period, with enormous pressure on the Board. My day began at the office at 7:30 in the morning and lasted until 7 or 7:30 at night. I took home a briefcase with a sandwich and reading material, ran for about three miles, and got into bed to work until midnight.

About 350 pages of reading material came across our desks everyday. Even with assistants and an excellent staff, it was still necessary to work every night. Volcker would come in at about 9:00 in the morning but seldom left before 9:00 at night. He lived in a little one-bedroom apartment about three blocks away, cooked his own dinner on a hot plate and worked until 1:00 or 2:00 at night. That was the way we lived for one solid year. I didn't read a book or watch a movie. I didn't turn on the TV except to watch the Super Bowl.

Unfortunately, things continued to get worse. In January the Carter administration submitted a budget that widened the deficit. The markets reacted dramatically, thinking that inflation was going to get out of control. There was a law on the books, which had been put in under President Nixon's administration, allowing credit controls. It was invoked by the President but administered by the Federal Reserve. When President Carter invoked credit controls, Volcker put me in charge.
That was the worst job I have ever had. I had a staff of about 80 economists, but you cannot imagine how enormously complex our economy is. Every time we put out a regulation to try to take care of one problem, we would find that we had created two or three others in the process. This economy is a remarkable invention. It works amazingly well, but when you interfere with it, myriad unanticipated problems are created. In the final analysis, people were reacting by cutting up their credit cards and restricting most of their borrowing. The economy dropped precipitously, and we removed the credit controls as quickly as we thought we could. We misjudged. The economy quickly overheated again, and we were put into the difficult position of having to raise interest rates in August, just prior to the election.

The Federal Reserve is a thoroughly nonpolitical institution. I never heard politics discussed at the Board table while I was there, but we did try to make any moves as far away from an election as possible. We were anxious not to be seen as trying to influence the outcome one way or the other. I don't think any Federal Reserve Board has ever increased rates as close to an election as we did. I got a call from a friend of mine at the White House who said, "What in the hell do you think you're doing?” I explained that we really didn't have a choice. If we didn't raise rates, the inflation problem would get worse and it would mean that we would have to raise them even more at a later time. He replied, "Well, you've got to do what you've got to do," and that was the end of it.

Jimmy Carter may have had his problems as President, but in certain settings he was as sharp as anybody I have ever seen. One Saturday night when we were working on credit controls, I was called to the cabinet room of the White House to meet with the President, Vice President, Secretary of the Treasury, and head of the Office of Management and Budget. President Carter's questions came like a machine gun. He was superbly knowledgeable and very much in charge.

During this period, we had a lot of international pressure as well. While I was there I can't remember a head of state who came to Washington without seeing Paul Volcker. I saw a lot of finance ministers and foreign ministers. The Fed was very 
much the focus of what was going on in the world. We were trying to explain to them what we were trying to do. I remember one meeting in Basel, Switzerland, of the Bank for International Settlements, which is a kind of central bankers' central bank. There are some 80 countries that are members, with 11 on the executive committee. The meeting begins on a Monday afternoon with a so-called "tour d'horizon," tour of the horizon, where each country on the executive committee reports on how they see the economy of the world. I was representing the United States, and the Governor of the Bank of England turned to me and said, "Well, I think we should first hear from the Federal Reserve because they're the elephant in the lifeboat."

The Vice Chancellor of Austria once came to my office to ask if I would be willing to do an interview with him, which he would use in his reelection campaign. I agreed on the condition that we just talk economics. Evidently he used the interview on television to explain Austria's economic problems. It must have worked, because he got reelected.

In January 1981, the Reagan administration took office. They were committed to the supplyside approach, which required a big cut in taxes. At the Federal Reserve we thought a tax cut would be helpful. Unfortunately, Congress commandeered the bill and the logrolling began. The special interests had a field day: wood stoves in Vermont, racehorses in Kentucky, peanuts in Alabama. It got so bad that in June the Reagan administration seriously questioned whether they should try to pass the bill. The Federal Reserve opposed it. Volcker had a number of meetings with members of the Senate and I with members of the House. About two weeks after the bill was passed, I saw Bob Dole in the elevator of the apartment house where we both lived. Even though he had helped pass the bill, he said, "I think you were right." He then put in a bill to rescind many of its most egregious provisions.

During the early years of the Reagan administration, there was a battle between the Treasury and the Fed. Don Regan was Secretary of the Treasury, and he had assembled an economic team of committed supply-siders who were concerned primarily with supporting their theory. When the economy didn't work in sync with their theories, they were quick to blame the Federal Reserve. After enduring this criticism from every direction, I finally bought a large child's top with a plunger to make it spin. I had it painted four different colors labeled "supply side," "Keynesianism," "monetarism," and "gold standard." I sent it to Don Regan with a note that he could have any kind of monetary policy he wanted if he just pushed the plunger up and down. Don was not a very good economist, but he had a quick wit. Three days later I received a box with a yo-yo in it and a note saying that everything would be all right if the Fed would stop yo-yoing the money supply. When Jim Baker came in as Treasury Secretary, he adopted a much more pragmatic approach and relationships with the Fed improved considerably.

Throughout the 1980s, problems were created by budget deficits and tight monetary policy. In 1990, President Bush recognized that this was not the optimum way to run economic policy. He proposed a tax increase. From an economic point of view, I think this was very right and very courageous, but it was politically devastating. When people are assessing credit for the extraordinary good times of the late 1990s, George Bush deserves some of the credit. When the Clinton administration took office, they raised taxes further to create a balanced budget. That enabled the Fed to lower interest rates. When combined with advances in technology, this encouraged businesses to dramatically increase their capital expenditures. The result was a surge of productivity that has enabled us to have a strong economy without inflation.

Now we are in a period where we have totally reversed the economic policies of the 70s. I don't know of any responsible Republican or Democrat who argues that we ought to have an unbalanced budget at this point in time. They may argue about the level of taxes or the level of spending, but no one espouses anything other than a tight fiscal policy with any necessary adjustments accomplished by a flexible monetary policy. The Achilles heel of the system is that it is deeply dependent upon the Chairman of the Federal Reserve. We have had the two greatest Federal Reserve Chairmen in history: Paul Volcker and Alan Greenspan. 


\section{Schultz}

Alan told me two years ago that "the people of the United States will never understand how much they owe to Paul Volcker." Paul had the intellect and the courage to handle the difficult crisis of the late 1970s and early 1980s. On the other hand, Alan Greenspan is the best I have ever seen in sensing where we are in the business cycle.

When I first got on the Board, I called former Chairman Arthur Burns and asked him to have lunch. I wanted to ask him what characteristics of a governor of the Federal Reserve were, in his opinion, the most important. He puffed on his pipe and in his gravelly voice replied, "Common sense and good judgment." The President of the United States will appoint a new Chairman of the Federal Reserve. He needs to find someone who is a brilliant and experienced economist, but more than anything else, he needs to find someone with common sense and good judgment. 